J. Amer. Soc Hort. Sci. 116(5):861-864. 1991.

\title{
Differences in Number and Area of Mesocarp Cells between Small- and Large-fruited Peach Cultivars
}

\author{
Ralph Scorza' \\ U.S. Department of Agriculture, Agricultural Research Service, Appalachian Fruit Research \\ Station, 45 Wiltshire Road, Kearneysville, WV 25430 \\ Lisa G. May and Beverly Purnell \\ Shepherd College, Shepherdstown, WV 25443 \\ Bruce Upchurch \\ U.S. Department of Agriculture, Agricultural Research Service, Appalachian Fruit Research \\ Station, 45 Wiltshire Road, Kearneysville, WV 25430 \\ Additional index words. Prunus persica, fruit development, fruit growth, histology
}

\begin{abstract}
The growth in diameter of large- ('Loring' and 'Suncrest') and small-fruited ('Bailey' and 'Boone County') peaches [Prunus persica (L.) Batsch] was recorded at weekly intervals from 175 days prebloom to ripening. Samples collected at three dates prebloom, full bloom (FB), and four dates postbloom, including ripe fruit, were sectioned and stained. Total cell count and mean cell size were determined for prebloom ovaries and postbloom mesocarp tissue. Large-fruited cultivars had significantly more cells (up to 3.7 times) than small-fruited cultivars at all sampling dates. Cell sizes increased dramatically with fruit development, but were similar for all cultivars within each sampling date. These results suggest that mesocarp cell count is the major difference between small- and large-fruited peach cultivars and that this difference is determined early in the growth of the ovary.
\end{abstract}

Large fruit size is an essential characteristic for commercial peach cultivars. Fruit size is a function of genotype and environment. Although the major factor affecting fruit size is genotype, within the genetic limitations of a particular cultivar, fruit size can be increased by early fruit thinning (Byers and Lyons, 1985; DelValle et al., 1985; Havis, 1962), girdling (FernandezEscobar et al., 1987), and the application of growth regulators (Byers et al., 1969; Hasegawa and Nakajima, 1988).

Fruit size has been regarded to be a function of cell division in the early stages of development and of cell enlargement in the final stages of fruit growth (Batjer and Westwood, 1958; Westwood et al,, 1967). Differences in peach fruit size among trees of the same cultivar have been shown to be chiefly due to differences in cell count, with cell size having a minor effect (Bradley, 1959). However, it is unclear whether differences in fruit size between cultivars is also due chiefly to differences in cell count.

The purpose of this study was to determine the basis for differences in fruit size between large- and small-fruited peach cultivars -and to determine the developmental stage during which these differences could first be observed.

\section{Materials and Methods}

Four peach cultivars were chosen to represent two size categories: 'Bailey' and 'Boone County' are small-fruited rootstock cultivars; 'Suncrest' and 'Loring' are large-fruited commercial cultivars. Trees were 8 years old at the beginning of the study. All trees were budded on seedling 'Lovell' root-

\footnotetext{
Received for publication 31 Dec. 1990. Mention of a trademark, warranty, proprietary product, or vendor does not constitute a guarantee by the U.S. Dept. of Agriculture and does not imply its approval to the exclusion of other products or vendors that may be suitable. The advice of Michael Wisniewski on thinsectioning techniques for this study and the technical help of John Cordts are gratefully acknowledged. The cost of publishing this paper was defrayed in part by the payment of page charges. Under postal regulations, this paper therefore must be hereby marked advertisement solely to indicate this fact.
}

stock. They were fertilized with $300 \mathrm{~kg} 10 \mathrm{~N}-4 \mathrm{P}-8 \mathrm{~K} / \mathrm{ha}$ and pruned to an open-center form each spring. In 1986, FB was determined as the time when $\approx 50 \%$ of flowers were fully opened. In 1987 and 1988, bloom was allowed to progress for 2 days following the first flush of open flowers; all flowers not fully opened were manually removed. Fruit were thinned to be $\approx 15$ to $20 \mathrm{~cm}$ apart at the initiation of endocarp hardening in June.

Fruit were sampled each year for diameter measurement. On each sampling date, 10 fruit were harvested from the midportion of shoots on each of one to three trees per cultivar, providing 10 to 30 fruit for each cultivar/sampling date combination from which to calculate mean fruit diameter.

Buds and fruit for histological studies were sampled from the midsection of shoots at the outer edge and midheight of the canopy. One tree of each cultivar was used throughout the study, having been selected from a block of four trees based on trueness to type, vigor, uniform distribution of scaffold branches, and absence of obvious disease. Fruits were collected for sectioning at $\approx 38,56$, and 101 days after bloom (DAB) and at firm ripe in the 1986 growing season; 41 and 49 days prebloom (DPB), FB, and 36 DAB in 1987; and 175 DPB during Fall 1987 before the 1988 growing season. Postbloom samples were fixed in formalin acetic alcohol, embedded in paraffin following the schedule outlined by O'Brien and McCully (1981), sectioned at $8 \mu \mathrm{m}$, and stained with $0.5 \%$ toluidine blue- 0 in $1 \%$ sodium carbonate. Prebloom samples were fixed in 3.570 gluteraldehyde in $0.25 \mathrm{M}$ phosphate buffer. Outer bud scales were removed from the 175-DPB samples before fixation. The gluteraldehyde solution was changed three times; vacuum aspiration was used to aid penetration. Samples were then dehydrated in a graded ethanol series, followed by two changes of propylene oxide. Infiltration of the samples followed the schedule outlined by Spurr (1969), using standard procedures for plastic

Abbreviations: DAB, days after bloom; DPB, days prebloom; FDP, fruit development period; FB, full bloom. 
embedding in Spurr's resin. Samples were sectioned on a LKB ultratome 2128 with a glass knife. Sections of $1 \mu \mathrm{m}$ were stained with $0.5 \%$ toluidine blue- 0 in $0.1 \%$ sodium carbonate $(\mathrm{pH} 11.1)$.

Two methods for counting cells were used. In the first, photographic negatives of sections were prepared using a $35-\mathrm{mm}$ camera and Kodak Technical Pan Film. The negatives were then projected on a sheet of paper using a slide projector placed at a fixed distance from the paper. A manual cell count was then made to determine the number of cells in the photographic negative of the sample. Measurement of cell areas was done by calibrating the ocular scale of the microscope with a micrometer scale and measuring cell diameter directly from the prepared slides. Cell areas were determined by using the equation for the area of an ellipse.

The second method involved the use of the Kontron Image Processing System (Kontron Image Processing Division, Elon College, N. C.) connected to a MicroVax computer. A solid state camera (Model \#4815; COHU, Electronics Division, San Diego) was attached to a microscope, and an image was digitized directly from the slide. A low-pass filter was applied to the image and then subtracted from the original image. This process reduced illumination variations in the image (Lim, 1984). Two binary images were formed by using a low and high threshold on the filtered image. The thresholds were adjusted until satisfactory images were acquired. A contoured image was formed from each binary image and overlaid on the other image. After visually inspecting each image, the image requiring the fewest modifications to conform with the original image (i.e., to extend cell walls) was edited. Then, each enclosed object (cell) in the image was identified and measured automatically. This specific program was standardized with known cell counts. Each calculated area was resealed from pixels to square millimeters based on the number of pixels within a micrometer scale. Cell size and count determinations using the Kontron Image Processing System were used for all cultivars at 34 to 38 DPB. Samples

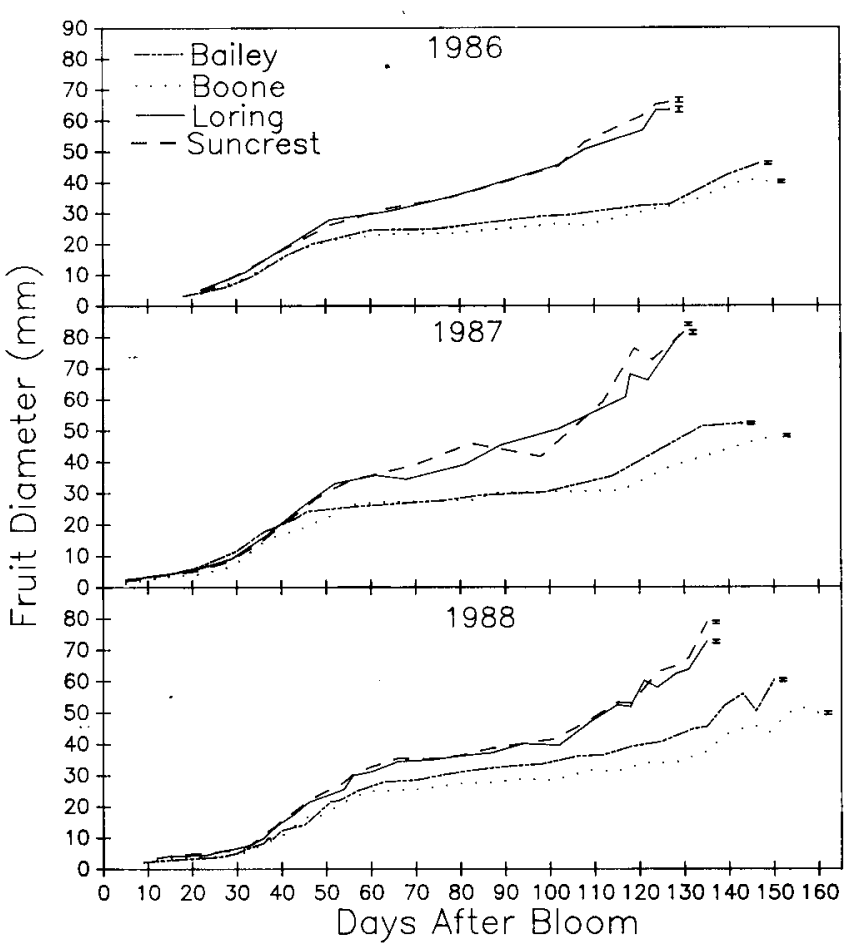

Fig. 1. Growth (in diameter) of peach fruit throughout postbloom development, 1986-88. Bars indicate mean SE.
Table 1. Peach fruit mesocarp cell number and cell area during fruit development.

\begin{tabular}{|c|c|c|c|c|}
\hline Date & $\begin{array}{c}\text { Development } \\
\text { period }^{z} \\
\text { Day } \pm \text { bloom }\end{array}$ & Cultivar & $\begin{array}{l}\text { Cells/whole-fruit } \\
\text { cross section } \\
\text { (thousands) }\end{array}$ & $\begin{array}{c}\text { Cell area } \\
\left(\mu \mathrm{m}^{2}\right)\end{array}$ \\
\hline \multicolumn{5}{|l|}{1987} \\
\hline \multirow[t]{4}{*}{14 Oct. } & -175 & Suncrest & $0.750 \mathrm{a}^{\mathrm{y}}$ & $75 a$ \\
\hline & -175 & Loring & $0.684 \mathrm{a}$ & $61 \mathrm{~b}$ \\
\hline & -175 & Boone & $0.310 \mathrm{~b}$ & $68 \mathrm{ab}$ \\
\hline & -175 & Bailey & $0.349 \mathrm{~b}$ & $60 \mathrm{~b}$ \\
\hline \multirow[t]{4}{*}{26 Feb. } & -49 & Suncrest & $2.07 \mathrm{a}$ & $70 \mathrm{~b}$ \\
\hline & -49 & Loring & $1.89 \mathrm{ab}$ & $80 \mathrm{ab}$ \\
\hline & -49 & Boone & $1.43 \mathrm{~cd}$ & $91 \mathrm{a}$ \\
\hline & -49 & Bailey & $1.06 \mathrm{~d}$ & $74 \mathrm{ab}$ \\
\hline \multirow{4}{*}{6 Mar. } & -41 & Suncrest & $2.23 \mathrm{a}$ & $89 a$ \\
\hline & -41 & Loring & $2.49 \mathrm{a}$ & $75 a$ \\
\hline & -41 & Boone & $1.48 \mathrm{~b}$ & $89 a$ \\
\hline & -41 & Bailey & $0.982 \mathrm{c}$ & $86 a$ \\
\hline 9 Apr. & FB & Suncrest & $19.5 \mathrm{a}$ & $101 \mathrm{a}$ \\
\hline \multirow[t]{2}{*}{13 Apr. } & FB & Loring & $19.1 \mathrm{a}$ & 99 a \\
\hline & $\mathrm{FB}$ & Boone & $11.2 \mathrm{c}$ & $102 \mathrm{a}$ \\
\hline 15 Apr. & FB & Bailey & $15.3 \mathrm{~b}$ & $85 \mathrm{~b}$ \\
\hline 15 May & +36 & Suncrest & $187 \mathrm{~b}$ & $319 \mathrm{~b}$ \\
\hline \multirow[t]{2}{*}{19 May } & +36 & Loring & 249 a & $405 \mathrm{a}$ \\
\hline & +36 & Boone & $170 \mathrm{~b}$ & $419 a$ \\
\hline 20 May & +35 & Bailey & $130 \mathrm{c}$ & $323 \mathrm{~b}$ \\
\hline \multicolumn{5}{|l|}{1986} \\
\hline \multirow[t]{4}{*}{15 May } & +38 & Suncrest & $210 \mathrm{a}$ & $340 \mathrm{~b}$ \\
\hline & +38 & Loring & $187 \mathrm{a}$ & $368 \mathrm{a}$ \\
\hline & +38 & Boone & $108 \mathrm{~b}$ & $400 \mathrm{a}$ \\
\hline & +34 & Bailey & $78.4 \mathrm{c}$ & $269 \mathrm{~b}$ \\
\hline \multirow[t]{4}{*}{9 June } & +56 & Suncrest & $217 \mathrm{a}$ & $3,810 \mathrm{a}$ \\
\hline & +56 & Loring & $187 \mathrm{~b}$ & $3,140 \mathrm{a}$ \\
\hline & +56 & Boone & $92.8 \mathrm{~d}$ & $3,420 \mathrm{a}$ \\
\hline & +56 & Bailey & $120 \mathrm{c}$ & $2,250 \mathrm{~b}$ \\
\hline 23 July & +107 & Suncrest & $371 \mathrm{~b}$ & $4,240 \mathrm{a}$ \\
\hline \multirow[t]{2}{*}{17 July } & +101 & Loring & $427 \mathrm{a}$ & $4,000 \mathrm{a}$ \\
\hline & +101 & Boone & $117 \mathrm{~d}$ & $4,080 \mathrm{a}$ \\
\hline 23 July & +103 & Bailey & $153 \mathrm{c}$ & $3,580 \mathrm{a}$ \\
\hline 8 Aug. & Ripe & Suncrest & 581 a & $10,500 \mathrm{a}$ \\
\hline 11 Aug. & Ripe & Loring & $564 a$ & $8,720 \mathrm{a}$ \\
\hline 3 Sept. & Ripe & Boone & $236 \mathrm{~b}$ & $9,330 \mathrm{a}$ \\
\hline 4 Sept. & Ripe & Bailey & $257 \mathrm{~b}$ & $7,840 \mathrm{a}$ \\
\hline
\end{tabular}

$z_{-,} \mathrm{DPB} ;+, \mathrm{DAB}$.

yMean separation within columns for each sampling date by Duncan's multiple range test, $P=0.05$.

consisted of four to six sections per fruit, three to four fruit per cultivar. Manual measurements from photographic negatives were used at all other sampling dates. Samples consisted of three to four sections per fruit, three to five fruit per cultivar. Cell counts from the same sample slide using the Kontron Image Processing System and the photographic method were within 5\% of each other (data not presented).

Vascular bundles were present in most samples at all sampling dates but were not numerous. When these areas could not be avoided in photographs or on the projected image, the vascular area was subtracted from the total image area and that calculated area used as the basis for cell count determination.

The area of the whole-fruit cross section was determined by directly measuring fruit diameter on postbloom fruit or by measuring the whole ovary median cross section under a microscope with a micrometer scale. The equation for the area of an ellipse was used for area calculation. The number of cells in a wholefruit cross section was then determined by the equation $\mathrm{x} / \mathrm{a}=$ $\mathrm{X}^{1} / \mathrm{A}^{1}$, where $\mathrm{x}=$ the number of cells in a sample cross section, 
Table 2. Increases in cell count and cell area during peach fruit development.

\begin{tabular}{|c|c|c|c|c|}
\hline Date & $\begin{array}{c}\text { Development } \\
\text { period }^{2} \\
\text { Day } \pm \text { bloom }\end{array}$ & Cultivar & $\begin{array}{c}\text { Increase in no. } \\
\text { cells/fruit } \\
\text { cross section }\end{array}$ & $\begin{array}{c}\text { Increase in } \\
\text { cell area }\end{array}$ \\
\hline \multicolumn{5}{|l|}{1987} \\
\hline \multicolumn{5}{|c|}{ From day -49 to: } \\
\hline & -41 & Suncrest & $1.1 \mathrm{x}$ & $1.3 \mathrm{x}$ \\
\hline & -41 & Loring & $1.3 \mathrm{x}$ & $0.9 \mathrm{x}$ \\
\hline & -41 & Boone & $1.0 \mathrm{x}$ & $1.0 \mathrm{x}$ \\
\hline & -41 & Bailey & $0.9 \mathrm{x}$ & $1.2 \mathrm{x}$ \\
\hline \multicolumn{5}{|c|}{ From day -41 to: } \\
\hline & $\mathrm{FB}$ & Suncrest & $8.7 x$ & $1.1 \mathrm{x}$ \\
\hline & FB & Loring & $7.7 x$ & $1.3 \mathrm{x}$ \\
\hline & FB & Boone & $7.5 x$ & $1.1 \mathrm{x}$ \\
\hline & FB & Bailey & $15.5 x$ & $1.0 \mathrm{x}$ \\
\hline \multicolumn{5}{|c|}{ From FB to: } \\
\hline & +36 & Suncrest & $9.6 x$ & $3.2 \mathrm{x}$ \\
\hline & +36 & Loring & $13.0 x$ & $2.9 x$ \\
\hline & +36 & Boone & $15.2 \mathrm{x}$ & $4.1 x$ \\
\hline & +36 & Bailey & $8.5 x$ & $3.8 \mathrm{x}$ \\
\hline \multicolumn{5}{|l|}{1986} \\
\hline \multicolumn{5}{|c|}{ From day +38 to: } \\
\hline & +56 & Loring & $1.0 \mathrm{x}$ & $8.5 \mathrm{x}$ \\
\hline & +56 & Boone & $0.9 \mathrm{x}$ & $8.6 x$ \\
\hline & +56 & Bailey & $1.5 \mathrm{x}$ & $8.4 x$ \\
\hline \multicolumn{5}{|c|}{ From day +56 to: } \\
\hline & +107 & Suncrest & $1.7 \mathrm{x}$ & $1.1 \mathrm{x}$ \\
\hline & +101 & Loring & $2.3 x$ & $1.3 \mathrm{x}$ \\
\hline & +101 & Boone & $1.3 \mathrm{x}$ & $1.2 \mathrm{x}$ \\
\hline & +103 & Bailey & $1.3 \mathrm{x}$ & $1.6 \mathrm{x}$ \\
\hline \multicolumn{5}{|c|}{ From day +101 through +107 to: } \\
\hline & Ripe & Suncrest & $1.6 x$ & $2.5 \mathrm{x}$ \\
\hline & Ripe & Loring & $1.3 \mathrm{x}$ & $2.2 \mathrm{x}$ \\
\hline & Ripe & Boone & $2.0 \mathrm{x}$ & $2.3 \mathrm{x}$ \\
\hline & Ripe & Bailey & $1.7 \mathrm{x}$ & $2.2 \mathrm{x}$ \\
\hline
\end{tabular}

z-, DPB; +, DAB.

$\mathrm{a}=$ the area of the sample cross section, $\mathrm{X}^{1}=$ the number of cells in the whole-fruit cross section, and $\mathrm{A}^{1}=$ the area of the whole-fruit mesocarp cross section. The area of fruit occupied by the stone was likewise measured and subtracted from the calculated fruit cross-sectional area. The number of cells in wholefruit mesocarp cross sections was then compared among the four peach cultivars at the sampling dates. Measurement data were subjected to analysis of variance and Duncan's multiple range test.

\section{Results and Discussion}

Peach fruit diameter increases were similar in the 3 years of this study (Fig. 1). At almost all sampling dates, including 175 DPB, there was a clear difference in cell count, but not in cell area, between the large- and small-fruited cultivars (Table 1). Growth of peach fruit has been generally divided into three stages: I) Rapid development and increase in pericarp size; II) Delayed size increase in the pericarp, rapid embryo development; III) Rapid increase in mesocarp size (Tukey, 1933). Before these readily observable peach fruit growth stages, we observed a period of rapid ovary enlargement that occurred between 41 DPB and FB. At this prebloom stage, enlargement appears to be due chiefly to cell multiplication with an average 9-fold increase in cell count (Table 2). Stage I can be divided into two events: IA, from FB until $36 \mathrm{DAB}$, where cell count
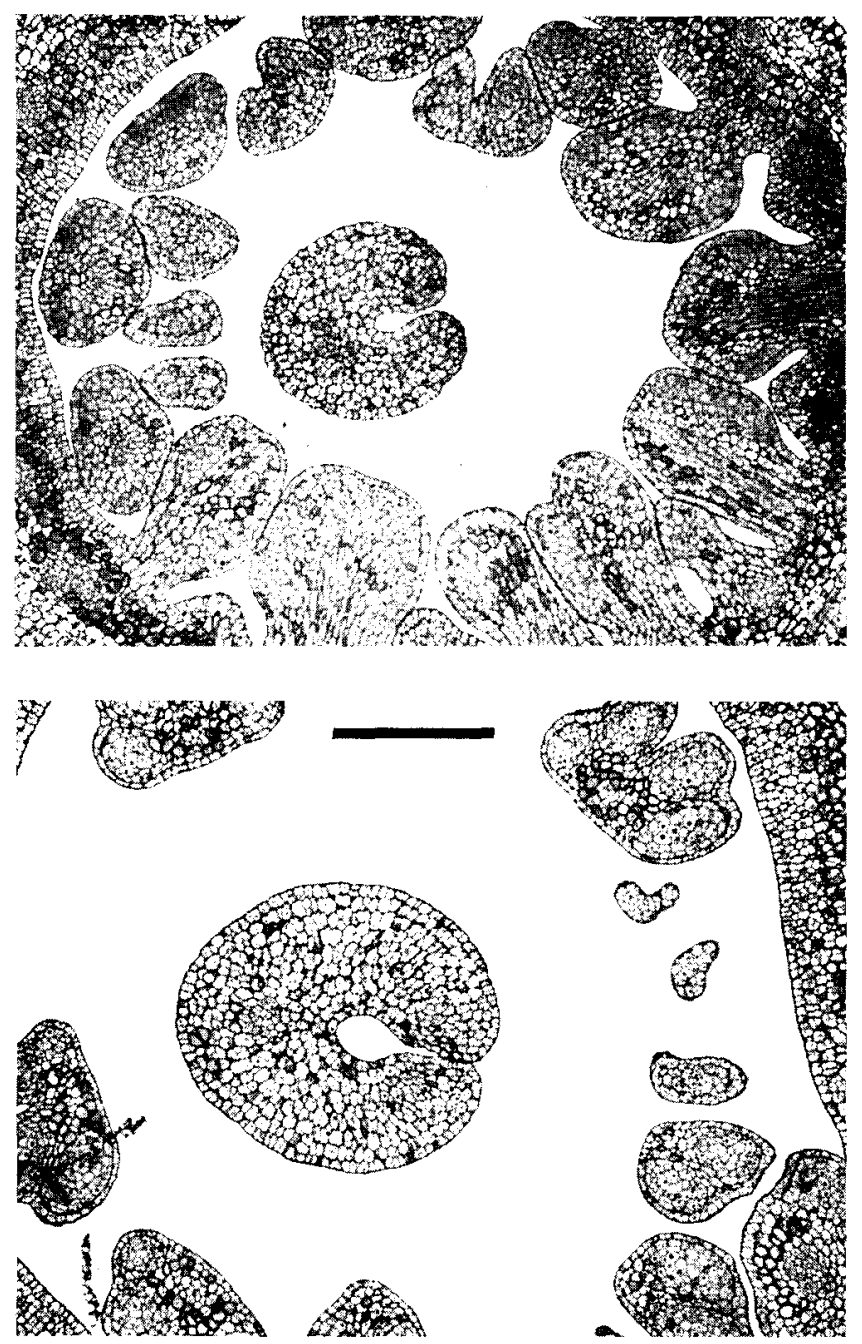

Fig. 2. Cross sections of the small-fruited 'Boone County' (top) and the large-fruited 'Loring' (bottom); ovaries $\approx 175 \mathrm{DPB}$. Bar $=0.1$ $\mathrm{mm}$.

increased 11.3 times and cell area 3.5 times; and IB, from 38 to $56 \mathrm{DAB}$, when cell count increased only 1.1 times but cell area increased an average of 9.2 times. During stage II, from $\approx \mathbf{5 6}$ to $107 \mathrm{DAB}$ for the larger, earlier-maturing cultivars and from 56 to $\approx 30 \mathrm{DAB}$ for the later-maturing, smaller-fruited cultivars, both cell division and cell enlargement were minimal, but both processes did occur, particularly cell multiplication of the large-fruited cultivars, which averaged a 2-fold increase. From 101 to 107 DPB to firm ripe (stage III), cell multiplication continued at a low level (1.5 times) but cell area increased an average of 2.3 times. The stage III increases in cell count and area were not as dramatic as those that occurred in earlier stages, but these relatively small increases affect many already enlarged cells and thus can produce the large observed increases in fruit size at this final stage of fruit enlargement.

Differences in size between large- and small-fruited cultivars were apparent as early as 175 DPB (Fig. 2) and were compounded as fruit developed (Fig. 3). During stage I, the rapid rate of increase in fruit size lasted, on average, $\approx 5$ days longer in the large-fruited than in small-fruited types (Fig. 1). During stage II, fruit of the large-fruited cultivars continued to enlarge, apparently due to cell multiplication, while enlargement of the small-fruited types was minimal. Further, while the small-fruited 


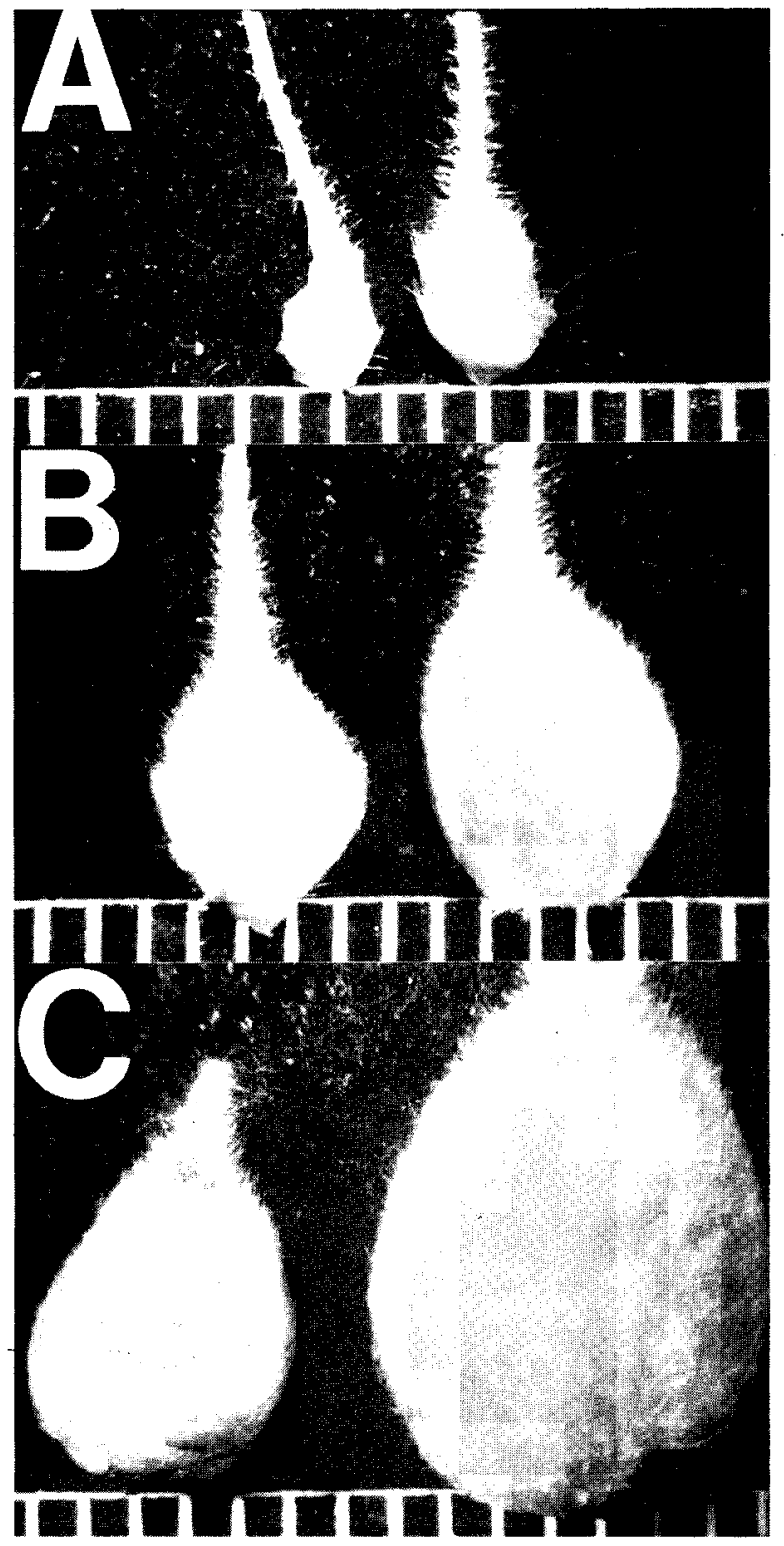

Fig. 3. Immature fruit of 'Boone County' (left) and 'Loring' (right) peaches at 5 (A), 15 (B), and 22 (C) DAB. Scale is in 1-mm increments.

types remained in stage II for $\approx 50 \%$ (70 to $80 / 150$ days) of their fruit development period (FDP), large-fruited types were in this stage for $\approx 30 \%$ (30 to $40 / 130$ days) of their FDP.

The results of this study indicate that differences in fruit size between large- and small-fruited cultivars are evident at 175 DPB and are likely the result of events that take place during the formation of flower primordia, as suggested for apples (Bergh, 1985). The basis for fruit size differences between cultivars is cell count and not cell size, as judged by cross-sectioned area. After these early differences in cell count have been established, other factors magnify differences in final fruit size; these include a longer period of time in stage I for large-fruited phenotypes, the relatively low percentage of time spent by large-fruited types in stage II, which is a period of limited cell multiplication and enlargement activity, and the relatively high cell multiplication rates that occur in the large-fruit types in stage II as compared to small-fruit cultivars.

Increases in fruit size apparently result from alternating periods of cell division and expansion throughout the FDP. Although a major period of cell division occurs early in fruit development and cell enlargement is important during "final swell" (stage III), cell division and cell expansion are not exclusive to either of these growth stages. Rapid growth during stage I is clearly an effect of this division-expansion process.

Large-fruited cultivars had 2.2 times more cells per ovary cross-sectional area than small-fruited cultivars at 175 DPB. This figure was 2.3 times for ripe fruit cross-sectional area. This consistency in relative size differences between large- and small-fruit cultivars from prebloom to ripe fruit indicates the importance of early prebloom events in determining ultimate fruit size. Most practices aimed at increasing fruit size, such as fruit thinning and girdling, are applied postbloom. Our study suggests that it may also be possible to produce major effects on fruit size by affecting early flower bud and ovary development.

\section{Literature Cited}

Batjer, L.P. and M.N. Westwood. 1958. Size of Elberta and J.H. Hale peaches during the thinning period as related to size at harvest. Proc. Amer. Soc. Hort. Sci. 72:101-105.

Bergh, O. 1985. Effect of previous crop on cortical cell number of Malus domestica cv. Starking Delicious apple flower primordia, flowers and fruit. S. Afr. J. Plant Soil 2:191-196.

Bradley, M.V. 1959. Mean cell size in the mesocarp of mature peaches of different sizes. Proc. Amer. Soc. Hort. Sci. 73:120-124.

Byers, R. E., H.C. Dostal, and F.H. Emerson. 1969. Regulation of fruit growth with 2-chloroethane phosphoric acid. Bioscience 19:903904.

Byers, R.E. and C.G. Lyons, Jr. 1985. Peach flower thinning and possible sites of action of desiccating chemicals. J. Amer. Soc. Hort. Sci. 110:662-667.

DelValle, T. G. G., J.A. Barden, and R.E. Byers. 1985. Thinning of peaches by temporary inhibition of photosynthesis with Terbacil. J. Amer. Soc. Hort. Sci. 110:804-807.

Fernandez-Escobar, R., R. Martin, P. Lopez-Rivares, and M. Paz Suarez. 1987. Girdling as a means of increasing fruit size and earliness in peach and nectarine cultivars. J. Hort. Sci. 62:463-468.

Hasegawa, K. and Y. Nakajima. 1988. The effects of KT-30 and GA paste treatment on the growth of peach fruit. Res. Rpt. Kochi Univ. Agr. Sci. 37:141-151.

Havis, A.L. 1962. Effects of time of fruit thinning of Redhaven peach. Proc. Amer. Soc. Hort. Sci. 80:172-176.

Lim, J.S. 1984. Image enhancement, p. 1-51. In: M.P. Ekstrom (cd.). Digital image processing techniques. Academic, New York.

O'Brien, T.P. and M.E. McCully. 1981. The study of plant structure, principles and selected methods. Termarcarphi Pty., Melbourne.

Spurr, A.R. 1969. A low-viscosity epoxy resin embedding medium for electron microscopy. J. Ultrastructure Res. 26:31-43.

Tukey, H.B. 1933. Growth of the peach embryo in relation to growth of fruit and season of ripening. Proc. Amer. Soc. Hort. Sci. 30:209218.

WestWood, M. N., L.P. Batjer, and H.D. Billingsley. 1967. Cell size, cell number, and fruit density of apples as related to fruit size, position in cluster, and thinning method. Proc. Amer. Soc. Hort. Sci. 91:51-62. 